\title{
E-Tongue : Lidah Elektronik Pendeteksi Rasa Manis, Asam, Asin, dan Pahit
}

\author{
Sintha Nur Fitriani*, Saqila Alifa R, Michelle Ferdinand, Lupita Churry A, Ai Masitoh \\ Program Studi Sarjana Farmasi, Fakultas Farmasi, Universitas Padjadjaran, Sumedang, 45363 \\ email: sinthafitriani04@gmail.com
}

\section{Abstrak :}

Pengukuran rasa dari suatu makanan biasanya dilakukan secara sederhana yaitu dengan tester manusia ataupun dengan kimia konvensional. Namun, pengukuran rasa menggunakan cara sederhana tersebut memiliki beberapa kelemahan diantaranya terkait dengan variabilitas individual, bersifat subyektif, membutuhkan adaptasi dan berbahaya bagi personel penguji. Demikian pula dengan metode pengukuran kimia konvensional yang cenderung sulit. Saat ini telah ditemukan instrument berbasis elektronik atau electronic tongue (e-tongue) yang mampu menganalisis secara cepat, akurat dan obyektif serta murah. Electronic tongue (e-tongue) dibangun atas sensor kimia berbasis membrane selektif ion. Sensor ini terbukti mampu digunakan untuk menguji lima rasa dasar yaitu asam, manis, pahit, asin dan gurih (umami).

Keyword: Pengukuran rasa, electronic tongue, membrane selektif ion

\section{Outline}

- Pendahuluan

- Deteksi rasa dengan sensor berbasis membrane selektif ion

- Kesimpulan

\section{Pendahuluan}

Rasa merupakan tanggapan indera pengecap terhadap rangsangan saraf seperti rasa manis, asam, asin, dan pahit. Dalam makanan tertentu, keempat rasa tersebut digabungkan untuk mendapatkan satu rasa yang menarik untuk dinikmati. Kemampuan untuk merasakan melalui indera pengecap secara umum sama namun berbeda dalam beberapa hal sehingga dapat dikatakan bahwa rasa itu bersifat subjektif bagi tiap orang.

Dalam pembuatan produk baru pasti dilakukan uji pengukuran rasa yang dilakukan melalui panelis (manusia pengujinya) yang bersifat subjektif dan harus melalui adaptasi terlebih dahulu. Sekarang, dirancang pengujian rasa secara elektronik.

Pengujian rasa tersebut dapat menggunakan sensor rasa elektronik atau electronic tongue (e-tongue) sehingga dalam mendeteksi rasa menjadi objektif, lebih cepat, akurat, dan murah. Pendeteksian ini didasarkan pada perbedaan potensial yang ditimbulkan. Hasil tersebut akan diklasifikasikan berdasarkan gabungan pola potensial yang terbentuk melalui sensor. 


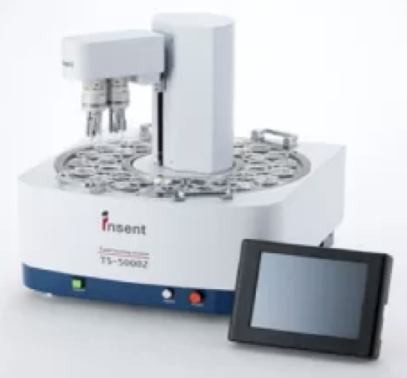

Gambar 1 Contoh Electronic tongue (pic : higuchi-inc.co.jp)

\section{Deteksi rasa dengan sensor berbasis membrane selektif ion}

Electronic tongue dibangun atas sensor kimia berbasis membran selektif ion yang hanya merespon terhadap ion-ion sampel yang berbeda muatan dengan membran. Membran yang digunakan berbasis lemak memainkan peranan penting dalam mendeteksi rasa pada sensor rasa.

Sensor rasa elektronik dibuat mirip seperti lidah manusia dengan direkatkannya membran lemak artifisial pada permukaan sensor sehingga ketika sensor menyerap rasa akan terjadi perubahan potensial pada membran lemak artifisial. Perubahan potensial direkam oleh komputer dan dibandingkan dengan pola rasa yang sudah ada. Zat yang memiliki rasa yang sama akan membentuk pola potensial yang sama.

Secara keseluruhan elektroda dicelupkan ke dalam sampel yang berupa larutan uji yang dihubungkan dengan ion meter. Kemudian sinyal masukan dari sensor disesuaikan oleh larutan penyangga (buffer) dari impedansi masukan tinggi menjadi impedansi keluaran rendah. Agar sinyal yang ditangkap sensor dapat diukur maka di perbesar oleh penguat (amplifier) sehingga dapat dibaca oleh komputer. E-tongue terdiri dari polianilin oligomer dan polipirol yang mampu membedakan larutan asin, manis, pahit, asam dan gurih (umami).

Pengujian terhadap lima kualitas rasa dasar yang dilakukan menggunakan sensor rasa elektronik menggunakan campuran membran dioktil fosfat dan trioktil metil amonium klorida dengan 5 sampel uji berbeda (setiap sampel dengan variasi konsentrasi memiliki nilai potensial yang berbeda-beda) yang masing-masing memiliki konsentrasi dari 0-100 mmol.

Membran berbasis dikotil fosfat (DOP) memberikan respon yang cukup tinggi untuk senyawa dengan rasa pahit karena sifat lipofilik sampel dengan rasa pahit yang memudahkan senyawa ini terekstrak ke dalam fasa membran yang bersifat lipofilik, namun karena komposisi dari DOP jauh lebih besar daripada trioktil methyl ammonium klorida (TOMA) maka efek dominasi DOP terlihat jelas.

\section{Kesimpulan}

E-Tongue dapat digunakan untuk mengukur lima rasa dasar secara akurat dan tidak subjektif serta dapat menggantikan fungsi lidah untuk membantu pengujian yang membutuhkan hasil pengukuran rasa secara objektif. 
Ikezaki H, Kobayashi Y, H Ikezazki, R Chen, Y Naito, K Toko. 2010. Advanced taste sensors based on artificial lipids with global selectivity to basic taste qualities and high correlation to sensory scores. Sens. 10:3411.

Riul A Jr, Gallardo Soto AM, Mello SV, Bone S, Taylor DM, Mattoso LH. 2003. An electronic tongue using polypyrrole and polyaniline. Synth Met132:109-16

Legin A, Rudnitskaya A, Di Natale C, Mazzone E, Amico. 2000. A D'pplication of electronic tongue for qualitative and quantitative analysis of complex liquid media. Sens Actuators $B$ : 65:232-4.

Hayashi, N., Chen, R., Ikezaki, H., dan Ujihara, T., 2008, Evaluation of the Umami Taste Intensity of Green Tea by a Taste Sensor, Agric. Food Chem., 56 (16), 7384.

Baullens, K., P'eter, M., Steven, V., Dmitriy, K., Andrey, L.,Saskia, B., Nathalie, C., Bart, M., dan Jeroen, L., 2008, Analysis of Tomato Taste Using Two Types of Electronic Tongues, Sensors and Actuators, B 131, 10-17.

Winquist, R. Bjorklund, C. Krantz-Rulcker, I. Lundstroma, K. Stergren, dan T. Skoglund, 2005. An Electronic Tongue in the Dairy Industry, Sensors and Actuators B ,111- 112, 299304. 